\title{
Assessment of Role of Flaxseed Mouth Freshener for Nutritional and Economic Upliftment of Flaxseed Growers
}

\author{
Neelu Vishwakarma ${ }^{1 *}$, Alpana Sharma ${ }^{2}$, D.K. Singh ${ }^{3}$ and Akhilesh Kumar \\ ${ }^{1} J N K V V$-Krishi Vigyan Kendra, Katni (MP), India \\ ${ }^{2} J N K V V$-Krishi Vigyan Kendra, Jabalpur (MP), India \\ ${ }^{3} \mathrm{JNKVV}$-Krishi Vigyan Kendra, Shahdol (MP), India \\ ${ }^{4}$ JNKVV-Krishi Vigyan Kendra, CoA, Rewa-486 001 (M.P.), India \\ *Corresponding author
}

A B S T R A C T

\section{Keywords \\ Mouth freshener, Omega- \\ 3 fatty acid, \\ Supplementation, \\ Hedonic ranking scale \\ Article Info \\ Accepted: \\ 18 October 2018 \\ Available Online: \\ 10 November 2018}

Flaxseed is known as a source of Omega-3 fatty acid. Alpha-Linolenic Acid (ALA) constitutes about $57 \%$ of the total fatty acid in flaxseed. There is a need to promote the use of Omega-3 fatty acid for nutritional requirements. Linseed contains a high amount of Omega-3. An enriched mouth freshener (containing Omega-3 fatty acid) was developed with incorporation of Flaxseed to evaluate sensory quality and nutritional value of the product. Flaxseed Mouth Freshener was standardized using organoleptic evaluation technique with help of 10 panel members using 9- point hedonic ranking scale. Results show that a small dose 15-20 gram of Flaxseed mouth freshener as daily intake significantly supplements Omega-3 fatty acid intake.

\section{Introduction}

Consumption of pan-masala, tobacco and gutaka have increased manifold despite statutory warning about their threat to human health. The major risk factors of tobacco use are high blood pressure, high body mass index, high cholesterol, high blood glucose as measured in disability-adjusted life years (DALYs) account for $61 \%$ of cardiovascular deaths in the world (WHO, 2009). 1 Linseed is an important source of Omega-3 fatty acid. Among all rabi oilseed crops in India, linseed is in the second position i.e. next to rapeseed- mustard in production. The most important property of this plant is that every part of the plant has specific economic importance.

The exceptional feature of nutritional significance of linseed is its abundance of polyunsaturated fatty acids, particularly omega-3 (n-3 or á-linolenic series) to the tune of $23.0 \mathrm{~g} / 100 \mathrm{~g}$ and omega- $6(\mathrm{n}-6$ or linoleic series) fatty acids to an extent of $7.2 \mathrm{~g} / 100 \mathrm{~g}$.

Madhya Pradesh is major linseed growing states in India. Linseed (Linum usitatissimum L) is an important oilseed crop but area under 
this crop has been reducing regularly. Every part of the linseed plant has specific economic importance. Its crushed seed/flour is used for value addition and for making various food preparations. Linseed oil has various industrial and medicinal uses. The stalk or straw is used for making flex fibre and papers. Indeed there is no herb as useful to mankind as is this crop for its interesting characteristics. Linseed is one of the vegetarian sources of Omega-3 fatty acid, which needs to be promoted to meet nutritional requirements. It is one of the cheapest and richest sources for vegetarian people cultivated by small farmers.

It's crushed seed /flour is used for value addition and for making various food preparations. One of the Omega-3 fatty acid, docosahexaenoic acid is the structural material for nervous tissue, including the brain. There is a need to promote the utilization of flax seed in a non-traditional linseed areas in dayto-day life owing to its health promote characteristics. Omega-3 fatty acids are among the most commonly prescribed supplements with a remarkable worldwide market because of its preventive nature of cardiovascular diseases. Epidemiological, PC, and RCT studies and meta-analyses, as well as several expert reviews and commentaries generally support the use of dietary sources of Omega-3. Deficiency of Omega-3 fatty acid may affect visual acuity, cognitive function and cardiovascular diseases. 2

The value-added product is one of the best strategies which farmers can employ to improve net profitability. Value-added products can open new markets, enhance the public's appreciation for the farms produce, and extend the marketability. Keeping all the above issues in mind a study was planned and conducted during 2014-16 to explore the utilization of flax seed to enrich the value added product in the form of Mouth Freshener.
The nutritional aspects and importance of Omega-3 fatty acid in human diet has enhanced its scope in agriculture. Scientific research over the past decade all over the world is indicating health benefits of Omega-3 type oils, lignin's and other soluble fibres present in the flax seed/linseed. Healthy Mouth Freshener with main ingredient as linseed has been developed and tested for different sensory attributes viz., colour, texture and taste (Table A).

\section{Materials and Methods}

Value added flaxseed in the form of mouth freshener was developed and standardized at Krishi Vigyan Kendra (Jabalpur 2014). The product was based on "Alpha-linolenic acid (ALA)" as omega-3 fatty acid is essential, being required for our body but our body cannot synthesise it. ALA plays important roles in human health. The flaxseed was procured from the local market.

The whole flaxseed grain was roasted till aroma develops. Coriander dal is prepared from the seeds of coriander. The treated seeds are highly flavoured and could be consumed as a digestive chew.

\section{Ingredients of Flaxseed Mouth Freshener (Omega-3 fatty acid riched)}

Linseed $=1 \mathrm{~kg}$

Dhaniya (Coriander) dal $=250 \mathrm{~g}$

Black Salt $=10 \mathrm{~g}$

Lemon juice $=15 \mathrm{ml}$

Ajwain powder $=20 \mathrm{~g}$

Turmeric powder $=10 \mathrm{~g}$

\section{Procurement of raw materials}

The various kinds of food stuffs viz., linseed, coriander dal black salt, lemon, celery, turmeric powder and zipp lock polythene bags etc. were purchased from local market. 


\section{Processing of flaxseed and coriander dal}

Flaxseed and coriander dal were cleaned to remove the dust and foreign materials. Bold seeded linseed and coriander dal were selected. Cleaned linseed and coriander dal was treated with fresh lemon juice, turmeric powder, and salt and kept to refrigerate for $2 \mathrm{hr}$ in air tight container. The product was than roasted on medium flame in open pan. The product was packed in plastic bags.

\section{Standardization of mouth freshener}

The product is standardized using organoleptic evaluation technique with the help of 10 panel members and 9-point hedonic ranking scale with range extremely liked (9) to extremely dislike (1). All the sensory quality attributes of mouth freshener were assessed i.e. appearance, colour, texture, taste and "feeling after taste" according to the method described by Amerine et al., (1965). SAS v9.4 software was used to analyse the data. Descriptive statistics with Wilcoxon Rank- Sum test were employed for valid conclusions. The nutrient composition of control flaxseed (plain roasted) and mouth freshener was calculated by table value chart (Gopalan et. al. 1999). The RTE flaxseed mouth freshener was stored about 30 days in air tight small size plastic containers.

\section{Results and Discussion}

The RTE mouth freshener prepared from flaxseed for supplementation of Omega-3 fatty acid. It is of dull brown in colour; salty in test with pleasant flavour and long-time chewing (Table 1). It is found suitable for substitute of supari or pan masala and is free from tobacco with nutritional benefits.

\section{Nutritional composition}

The flaxseed is small, flat, oval, brown (or fawn or yellow) coloured, glossy in appearance with mucilaginous taste and oily nature. The nutritional values of golden flaxseed vs. brown flaxseed are very similar if the samples are of the same quality (Table 2). contains:
Omega-3 (ALA) 6,338mg.
Fiber 8g.
Protein $6 \mathrm{~g}$.
Vitamin B1 31\% RDA
Manganese 35\% RDA
Magnesium 30\% RDA
Phosphorus 19\% RDA
Selenium 10\% RDA

A 1 ounce (3 tbsp) serving of flaxseeds

Also, flaxseeds contain a good amount of vitamin B6, Iron, potassium, copper and zinc.

The main constituent of flaxseed is $30-45 \%$ of fixed oil. It also contains about $6 \%$ mucilage which resides in seed coat and about $25 \%$ of protein together with wax, resin, sugar, phosphates and xanthophylls, vitamin viz. Thiamine, riboflavin and niacin and small quantity of cynogenic glucoside linamirin. Being rich source of alpha linoleic acid it improves immunity and lowers risk of stroke and other cardio vascular diseases (Chauhan $e t$ al., 2009).

\section{Acceptability of the product}

The product was found rich in omega -3 fatty acid, calcium, iron and protein. About one to two servings a day of this product will supplement the Omega-3 fatty acid. Product was also rich in Omega-3 fatty acid 15.96 $\mathrm{mg} / 100 \mathrm{gm}$.

These products were standardized and found more acceptable as compared to the control. Median overall acceptability for control was found $6.11 \pm 0.8$ whereas it is found higher in value added product i.e. $2^{\text {nd }} 7.3 \pm 0.8$. 
Table.A Recommendations for EPA and DHA Intake (Rev 16 April 2014)

\begin{tabular}{|c|c|c|c|c|}
\hline Country & Organization & $\begin{array}{l}\text { ORG. Type } \\
\text { Expert Scientific } \\
\text { organization }\end{array}$ & $\begin{array}{l}\text { Target } \\
\text { population }\end{array}$ & Recommendation \\
\hline India & $\begin{array}{l}\text { Cardiology Society } \\
\text { of India }\end{array}$ & $\begin{array}{l}\text { Expert Scientific } \\
\text { Organization }\end{array}$ & $\begin{array}{l}\text { For patients } \\
\text { with high } \\
\text { triglycerides } \\
\text { and patients } \\
\text { after MI for } \\
\text { secondary } \\
\text { prevention }\end{array}$ & $\begin{array}{lr}* \text { Omega } & -3 \text { fatty } \\
\text { acid } & \text { ethyl } \\
\text { esters(2-4 } & \text { g/day) }{ }^{6}\end{array}$ \\
\hline
\end{tabular}

Source: Indian Heart Journal (2012) 64:503-7.

Table.1 Summary of sensory scores for flaxseed mouth freshener in comparison with control

\begin{tabular}{|l|l|c|r|}
\hline S. N. & Parameters & \multicolumn{1}{|c|}{$\begin{array}{c}\text { Control } \\
\text { Vedian (Range) }\end{array}$} \\
\hline 1 & Colour and appearance & $5.75(1.9)$ & $7.28(1.0)$ \\
\hline 2 & Texture & $5.40(1.2)$ & $6.85(1.6)$ \\
\hline 3 & Taste & $6.85(1.6)$ & $7.75(1.6)$ \\
\hline 4 & Flavour & $6.20(1.1)$ & $7.20(1.8)$ \\
\hline 5 & Overall acceptability & $6.11(0.8)$ & $7.30(0.8)$ \\
\hline
\end{tabular}

Table.2 Nutritive value of prepared products - Plain Roasted and Flaxseed Mouth Freshener

\begin{tabular}{|l|c|c|c|c|}
\hline \multicolumn{1}{|c|}{ Nutrients } & \multicolumn{2}{|c|}{ Plain Roasted } & \multicolumn{2}{c|}{ Healthy Mouth Freshener } \\
\hline & Per 100 g & Per serving (10 g) & Per 100 g & Per serving (10 g) \\
\hline Protein (g) & 18.29 & 1.82 & 13.24 & 1.32 \\
\hline Fat (g) & 42.16 & 4.21 & 29.51 & 2.95 \\
\hline Saturated (g) & 3.66 & 0.36 & 2.56 & 0.25 \\
\hline Mono unsaturated(g) & 7.53 & 0.75 & 5.26 & 0.52 \\
\hline Polyunsaturated(g) & 28.73 & 2.87 & 20.11 & 2.01 \\
\hline Omega-3(g) & 22.8 & 2.28 & 15.96 & 1.59 \\
\hline Omega-6(g) & 5.9 & 0.59 & 4.13 & 0.41 \\
\hline Calcium (mg) & 255 & 25.5 & 229.7 & 22.97 \\
\hline Phosphorous(mg) & 642 & 64 & 449.4 & 44.94 \\
\hline Iron (mg) & 5.73 & 0.57 & 6.25 & 0.62 \\
\hline Fibre (g) & 27.3 & 2.73 & 19.11 & 1.91 \\
\hline Carbohydrate (g) & 28.88 & 2.88 & 24.10 & 2.41 \\
\hline Energy (k cal) & 534 & 53.4 & 482.6 & 48.26 \\
\hline
\end{tabular}

Nutritive value was calculated by table value given by Gopalan et al., (1999). 


\section{Int.J.Curr.Microbiol.App.Sci (2018) 7(11): 2276-2282}

Fig.1 Box-plot for four parameters to assess the quality of flaxseed Mouth Freshener
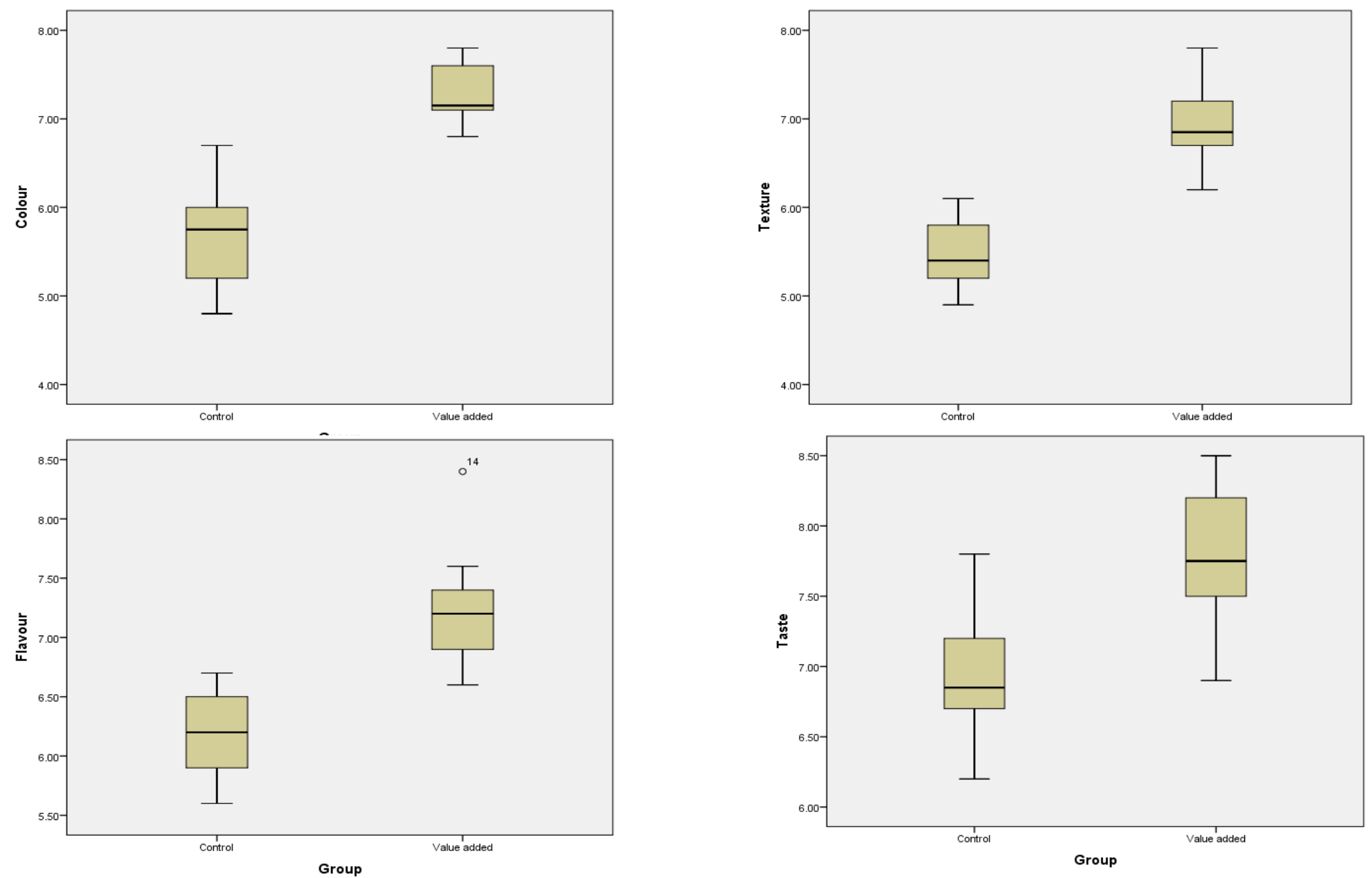
Table 3: Hypothesis test summary

\begin{tabular}{|c|c|c|c|c|}
\hline & Null Hypothesis & Test & Sig. & Decision \\
\hline 1 & $\begin{array}{l}\text { The distribution of Colour is the } \\
\text { same across categories of Group. }\end{array}$ & $\begin{array}{l}\text { Independent- } \\
\text { Samples } \\
\text { Mann- } \\
\text { Whitney U } \\
\text { Test }\end{array}$ & $.000^{1}$ & $\begin{array}{l}\text { Reject the } \\
\text { nufl } \\
\text { hypothesis. }\end{array}$ \\
\hline 2 & $\begin{array}{l}\text { The distribution of Texture is the } \\
\text { same across categories of Group. }\end{array}$ & $\begin{array}{l}\text { Independent- } \\
\text { Samples } \\
\text { Mann- } \\
\text { Whitney U } \\
\text { Test }\end{array}$ & $.000^{1}$ & $\begin{array}{l}\text { Reject the } \\
\text { nufl } \\
\text { hypothesis. }\end{array}$ \\
\hline 3 & $\begin{array}{l}\text { The distribution of Taste is the } \\
\text { same across categories of Group. }\end{array}$ & $\begin{array}{l}\text { Independent- } \\
\text { Samples } \\
\text { Mann- } \\
\text { Whitney U } \\
\text { Test }\end{array}$ & $.001^{1}$ & $\begin{array}{l}\text { Reject the } \\
\text { null } \\
\text { hypothesis. }\end{array}$ \\
\hline 4 & $\begin{array}{l}\text { The distribution of Flavour is the } \\
\text { same across categories of Group. }\end{array}$ & $\begin{array}{l}\text { Independent- } \\
\text { Samples } \\
\text { Mann- } \\
\text { Whitney U } \\
\text { Test }\end{array}$ & $.000^{1}$ & $\begin{array}{l}\text { Reject the } \\
\text { nufl } \\
\text { hypothesis. }\end{array}$ \\
\hline 5 & $\begin{array}{l}\text { The distribution of Overall is the } \\
\text { same across categories of Group. }\end{array}$ & $\begin{array}{l}\text { Independent- } \\
\text { Samples } \\
\text { Mann- } \\
\text { Whitney U } \\
\text { Test }\end{array}$ & $.000^{1}$ & $\begin{array}{l}\text { Reject the } \\
\text { nufl } \\
\text { hypothesis. }\end{array}$ \\
\hline
\end{tabular}

Asymptotic significances are displayed. The significance level is .05 .

${ }^{1}$ Exact significance is displayed for this test.

Source: Generated through SPSS v23.0

Table.4 Economics of value added products

$\mathrm{BCR}=$ Benefit cost ratio $\mathrm{GR}=$ Gross return and $\mathrm{TC}=$ Total cost

\begin{tabular}{|l|l|l|l|l|}
\hline Particulars & Input cost(Rs) & Output(Rs) & Net return(Rs.) & Benefit cost ratio \\
\hline Raw materials (qt) & 4000 & 10800 & 4580 & $1: 1.7$ \\
\hline Labour cost & $10 @$ Rs212/day & & & \\
\hline Packaging & 100 & & & \\
\hline Total & 6220 & &
\end{tabular}

Figure 1 presents separate box-plot for each parameter assessed to evaluate the quality of flaxseed mouth freshener. The diagram reveals that there is clear-cut significant difference between control and value added product.

Table 3 represents the hypothesis test summary of the distribution of colour, texture, taste, flavor and overall acceptability were not found same across categories of groups i.e. control and value added with statistical significance $(\mathrm{p}<0.0001)$. Independent samples MannWhitney $U$ test has been applied to test this hypothesis as data was not normally distributed.

Addition of linseed having Omega-3 fatty acid improves the nutritive quality of Flaxseed mouth freshener and is good for health and 
could serve as key to reduce tobacco use in our country. It requires attention to promote healthy mouth freshener which may reduce many diseases which are caused due to tobacco consumptions.

\section{Economics of value added products}

After adopting this value addition technology the net return of flaxseed mouth freshener increases up to Rs 4580/-which results in a higher B: C ratio of 1.7 (Table 4).

Technology to formulate the flaxseed mouth freshener was disseminated through trainings. The technology serve as a substitute for the Healthy mouth Freshener. The shows a positive impact by direct and indirect effects on their personal health and by uplifting the income level.

\section{References}

Amit J. Jhala and Linda M. Hall, Flax (Linum usitatissimum L.): Current Uses and Future Applications, Canada. Australian Journal of basic and Applied Sciences, 4(9): 43044312, ISSN 1991-8178, 2010

Banakar, R., 2005, Fonnulation, nutritional quality and growth promoting characteristics of supplementary food. M.H.Sc. Thesis, Uni. Agric. Sci., Dharwad (India)

Chauhan, M.P., Sadhna Singh and Ashok Kumar Singh, Post-Harvest Uses of Linseed, J Hum Ecol, 28(3): 217-219 (2009).

Dalal JJ Kasliwal RR Dutta AL Sawhney JP Iyengar SS Dani S Desai N Sathyamurthy I Rao D Menon A Dasbiswas A Wander GS Chadha M Hiremath MS Roy DG Gupta V and Shivakadaksham N, Role of omega-3 ethyl ester concentrate in reducing sudden cardiac death following myocardial infarction and in management of hyper triglyceridemia: an Indian consensus statement. Indian Heart J 64:503-7. [online] (2012).

http://www.ncbi.nlm.nih.gov/pmc/articles/P MC3861206/pdf/main.pdf

Deepmala Singh, Prahalad Mishra and D.K Singh, Role of Voluntary Organizations in Promoting House Hold Livelihoods Indian Journal of Extension Education Vol. 52, No. 3 \& 4, 2016 (192-195)

Jump, D. B., Depner, C. M., \& Tripathy, S. Omega-3 fatty acid supplementation and cardiovascular disease: Thematic Review Series: New Lipid and Lipoprotein Targets for the Treatment of Cardio metabolic Diseases. Journal of Lipid Research, 53(12), 2525-2545, (2012).

Meenu Preethi, B., Karnataka 2010, Utilization of linseed for value addition to supplementary food* Department of Food Science and Nutrition, University of Agricultural Sciences, Dharwad J. Agric. Sci., 23 (5): (765-768),

Preethi B.M. and Chimmad B.V. (2010). Utilization of linseed for value addition to supplementary food. Karnataka J. Agric. Sci., 23 (5):765-768.

Rajendra R Chapke, VR Bhagwat and JV Patil, Impact of National Training on Sorghum Cultivation for Value-addition Indian Journal of Extension Education Vol. 51, No. $1 \& 2,2015(78-83)$

World Health Organization (2009). Global health risks- Mortality and burden of disease attributable to selected major risks ISBN 97892 4-156387 1.

\section{How to cite this article:}

Neelu Vishwakarma, Alpana Sharma, D.K. Singh and Akhilesh Kumar. 2018. Assessment of Role of Flaxseed Mouth Freshener for Nutritional and Economic Upliftment of Flaxseed Growers. Int.J.Curr.Microbiol.App.Sci. 7(11): 2276-2282. doi: https://doi.org/10.20546/ijcmas.2018.711.255 